\title{
Social Work Practice Behaviors and Beliefs: Rural-Urban Differences?
}

\author{
Tom A. Croxton \\ Srinika Jayaratne \\ Debra Mattison
}

\begin{abstract}
There is continuing debate within the social work profession on whether there are significant differences in the practice behaviors and beliefs between rural and urban dinical social workers and whether different standards should be applied in defining ethical practices. This study measures those differences with regard to five practice behaviors: bartering, maintaining confidentiality, competent practice, dual relationships, and social relationships. Differences were found in beliefs regarding the appropriateness of professional behavior though such differences did not translateinto practice behaviors. Moresignificantly, the research suggests considerable confusion about the meanings of ethical standards and the utilization of intervention techniques without formal training across both urban and rural social workers.
\end{abstract}

Keywords: Social workers, ethics, urban-rural, standards of practice, practice behaviorsbeliefs

\begin{abstract}
ociologists continue to debate whether urban/rural dichotomies are any Jonger of great significance (Castle, 1995; Johnson \& Wang, 1997; Nelson \& Smith, 1999). A similar debategoes on in nearly all professions (Erickson, 2001; Lyckholm, Hackney \& Smith, 2001; Roberts, Battaglia, Smithpeter \& Epstein, 1999), including social work (Carlton-LaNey, Edwards \& Reid, 1999; Davenport \& Davenport, 1995; Ginsberg, 1998a; Martinez-Brawley, 1999). What is clearly evident in these debates is the dearth of empirical evidence on the differences, if any, in the practice behaviors and professional beliefs of rural and urban social workers in the context of ethics. Questions such as whether community dynamics influence the ethical standards by which social workers practice, or whether there are differences between rural and urban social workers with regard to their ethical beliefs are largely answered with anecdotes or personal opinions (Jerrell \& Knight, 1985; Mazer, 1976; Miller, 1994). This study is a beginning effort toward answering these questions with empirical data in the context of clinical practice.
\end{abstract}

Tom A. Croxton, J.D., M.S.W. is Professor, School of Social Work, The University of Michigan. Srinika Jayaratne, Ph.D. is Professor, School of Social Work, The University of Michigan. Debra Mattison, M.S.W., A.C.S.W., B.C.D. is a Clinical Social Worker, St. Joseph Mercy Hospital, and Adjunct Lecturer, School of Social Work, The University of Michigan.

Copyright 2002 Advances in Social Work Vol. 3 No. 2 (Fall 2002) 117-132.

Indiana University School of Social Work. 


\section{URBAN/RURAL DIFFERENCESIN SOCIAL WORK PRACTICE}

Mermelstein and Sundet (1995) ask, "Are things so basically different about urban and rural contexts that we can justify a specialty, a title, a journal, a special alcove in the halls of social work? Increasingly the answer is 'NO'” (p. 5). In a study related specifically to professional practice roles and perceptions of client problems, York, Denton and Moran (1989) found no differences between rural and urban social workers. This research corroborates the study by Whitaker (1986), which found few differences between rural and urban social workers with regard to practice roles. There may also be few differences in the service needs and desires of urban and rural clients and the ways in which social services are delivered (Austin, Mahoney \& Seidl, 1978; Young \& Martin, 1989). Whether there are differences between rural and urban social workers within the realm of ethics is unknown.

Despite the lack of supporting empirical evidence, many who practice or identify with the helping professionals in rural communities continue to assert the doctrine of difference. Doelker and Bedics (1983), Ginsberg (1998a), Green and Webster (1976), and Martinez-Brawley (1993; 1999), for example, maintain that the unique features of rural social work practice require a special curricular focus in social work education, if not a specialty in rural practice. In addition, there is growing textbook literature on the special aspects of rural practice, all pointing to differences between rural and urban social work practice (Farley, Griffiths, Skidmore \& Thackeray, 1982; Ginsberg, 1998a; Gumpert \& Saltman, 1998; Johnson, 1980; Jones, 1993; Jones \& Zlotnick, 1998; Weitz, 1992).

Waltman (1986) maintains that the differences between urban and rural social work practice are so significant as to warrant special attention from the profession. Sobel (1992) argues that in rural communities, "Psychotherapists, to be successful, must create systems within their own community and they must be willing to make compromises in professional standards and ethical guidelines to effectively establish themselves as members of the health professionals within the community where their practices are located" (p. 62). Sobel concludes that, "It is important to remember when practicing in small towns, strict adherence to ethical codes cannot always be made" (p. 69). Sterling (1992) states that, "Therapists in small communities have to create their own rules and guidelines and develop their own means of managing (boundary and confidentiality) issues" (p. 113). Within the context of bartering for professional services, Reamer (2001) notes that, "Many believe that barter is appropriate in limited circumstances when it can be demonstrated that such arrangements are an accepted practice among professionals in the local community (p. 24). Ginsberg (1998a) also asserts that social workers in rural areas find they must adapt and modify traditional approaches to social work practice as taught in social work education.

Throughout this literature, academics and practitioners argue that practice and ethical standards adopted by professions are derived from an urban perspective and experience and do not take account of the rural environment. In essence, the call is for a "locality rule" as defined by local custom, which would hold rural practitioners to the professional standards of care, including ethical standards practiced in their community. In recognition of the difference between rural and urban professional norms, such a doctrine would, among other behaviors, allow greater 
flexibility for rural practitioners when interpreting the meaning of various provisions of the social work code of ethics. While such assertions may make intuitive sense, there is little empirical evidence that can be cited to support it.

In recognition of the continuing debate on rural/urban differences within the context of professional ethics, the research reported here identifies five professional behaviors where differences between rural and urban social workers in direct practice have been asserted: 1) Bartering; 2) Maintaining confidentiality; 3) Competency; 4) Entering into dual or multiple relationships with clients; and 5) Forming social relationships with clients. These behaviors and professional beliefs about their appropriateness are the primary foci of this study.

\section{BARTERING: THE EXCHANGE OF GOODSAND SERVICES AS PAYMENT FOR TREATMENT}

Gutheil and Gabbard (1993), Kagle and Giebelhausen (1994), Pope (1991), and Simon and Williams (1999) argue that bartering is so fraught with potential conflicts in the professional relationship that it should always be avoided. Yet, bartering is viewed by some as part of the traditional cultural landscape in rural communities (Miller, 1994). Jennings (1992) maintains "that there are some special circumstances which emerge in rural settings in which bartering is justified and even desirable" (p. 101). The Clinical Social Work Federation Code of Ethics (1997) permits bartering arrangements, but "only in rare occasions" and "only (when the arrangements) involve the provisions of goods, as opposed to services, in exchange for treatment" (CSWF, PrincipleV.d).

Despite recognizing the dangers inherent in bartering, the National Association of Social Workers (NASW) Code of Ethics Revision Committee did not recommend a categorical prohibition of bartering and opted for a "last resort" rule, but only in the context of community custom; that is, bartering is accepted among professionals in the local community (Reamer, 1998). The current NASW Code of Ethics (1996) warns of the dangers of accepting goods and services as payment for professional services, but permits bartering "if it can be demonstrated that such arrangements are accepted practice among professionals in the local community, considered to be essential to the provision of services, negotiated without coercion and entered into on the client's initiative and with the client's informed consent" (NASW, 1996, Sec. 1.13).

This would appear to be an adoption of a "locality rule" within the context of ethics. However, in allowing bartering under limited circumstances, the Code also attaches a caveat warning to the social worker that he or she has the "full burden of demonstrating that this (bartering) arrangement will not be detrimental to the client or the professional relationship" (NASW, 1996, Sec. 1.13). Miller (1994) laments that this caveat may be seen by social workers as placing them in a too precarious or ethically risky position; hence, arrangements otherwise beneficial to the rural client and community will be lost.

Despite the debate on bartering and the current stance of various codes of ethics (American Psychological Association, 1992; CSWF, 1997; NASW, 1996), very little is known about the extent of bartering as a common professional practice in rural 
communities. While Borys and Pope (1989) found a significant difference of opinion in the ethics of bartering among both social workers and psychologists, they also found its use as a method of payment for professional services to be relatively rare in practice. However, the extent to which rural social work practitioners actually enter into bartering arrangements and what they believe about the appropriateness of such behavior is otherwise largely unknown.

\section{CONFIDENTIALITY}

Nearly all commentators on professional practice in rural communities write about the lack of professional and individual privacy and the strains on principles of confidentiality (Cook, Hoas \& Joyner, 2001; Ginsberg, 1998b; Schank, 1998; Schank \& Skovholt, 1997). For example, Simon and Williams (1999) observe that family and community members may mount considerable pressure on the therapist for information about the client. Spiegel (1990) notes that, "The maintenance of confidentiality in psychotherapy in a small-town rural setting is constantly threatened because social, hospital, industrial, and educational counseling services overlap, and people know each other well" (p. 637). Waltman (1986) states that preserving confidentiality is of utmost importance in the therapeutic relationship with a rural client. However, confidentiality is a sacred professional principle whatever the context of practice (Jaffee v. Redmond, 1996; NASW, 1996). Except in limited contexts such as "duty to warn," child and elder abuse, or responding to the suicidal patient, there is little debate on the sanctity of confidentiality in all social work-client communications (NASW, 1996; Reamer, 1999).

There also seems to be little doubt that the knowledge of a therapist/ client relationship is more widespread in a small or rural community and that there is easier access to the therapist by interested others in a rural environment. In most cases, entry into professional offices by known townspeople is clearly observable. However, doesthis mean that the principle of confidentiality takes on new meanings or presents different dilemmas in a rural environment? Again, most of the conclusions in answer to this question are based on anecdotal evidence and generalizations, perhaps even myths, about the current realities of the rural community.

\section{COMPETENCY}

Much of the social work literature on rural practice defines the role of the social worker within the context of a "generalist practice" (Davenport \& Davenport, 1995; Ginsberg, 1998b; Martinez-Brawley, 1999). Under the general ist model of practice, the social worker must be competent to work with different systems such as families, groups, organizations, and communities (Tolson, Reid \& Garvin, 1994).

Hargrove (1986) states, "In rural practice, the generalist model of practice prevails because of the lack of available resources and professionals. As a consequence, the rural psychologist is likely to be called upon to respond to a broad range of problems and people" (p. 374). Hence, without referral resources, the therapist finds herself in situations where the choice is either to provide treatment despite her limitations, or to provide no treatment at all (Welfel, 1998). In addressing this dilemma, Hargrove notes, "The most appropriate response to this ethically murky situation is not at all clear" (p. 374). Within the context of clinical practice, 
Sobel (1992) asserts, "Small town practitioners may be called upon to treat situations with which they may not feel totally competent, but realizing alternative services are a great distance away, may choose to do so in order to keep the patient functioning in the community with support and other health and mental health professionals" (p. 62). Roberts, Battaglia, \& Epstein (1999) al so notethat rural practitioners commonly perform professional work with broadened responsibilities, more independence, and a heightened need for specialist support, but with less training and supervision and fewer resources than their urban counterparts. Despite these assertions, the authors lack empirical data that indicates the extent to which practitioners employ intervention techniques for which they havehad no training or whether there are, in fact, differences between rural and urban practitioners regarding levels of success with clients.

\section{MULTIPLE AND DUAL RELATIONSHIPS}

According to Rinella and Gerstein (1994), allegations of ethical misconduct based in dual relationships are becoming increasingly common. Younggren and Skorka (1992) define dual relationships as "any relationship that runs concurrently with the therapeutic relationship" (p. 32), giving examples as friends, lovers, and business associates. Other examples would include therapeutic relationships with relatives, neighbors, political, or committee associates (Pope, 1991; Reamer, 1994).

The NASW Code of Ethics (1996) responds to concerns over the meaning of dual relationships in the professional context by stating, "The social worker should not condone or engage in any dual relationships with clients or former clients in which there is a risk of exploitation or potential harm to the client" (NASW Code, Sec. 1.06(c)). Since former clients often return for help when new problems arise (Hartlaub, Martin \& Rhine 1986; Mattison, Jayaratne \& Croxton, 2002; Robison \& Reeser, 2000; Silbertrust, 1993), one might argue that the potential harm of intervening relationships is always present. The Code does not provide a definition of risk in this instance, thereby, placing the burden on the practitioner.

Despite the provision in the NASW Code of Ethics with regard to dual relationships, there is very little in the professional literature to guide social work practitioners in more specific terms (Ramsdell \& Ramsdell, 1993; Rinella \& Gerstein, 1994). Thompson (1990), for example, asserts that dual relationships introduce competing interests and pose a "major threat" to the therapeutic process, that "friendships, for example, are reciprocal and, thus, would require the focus of therapy to shift from one party to the other, from one set of interests to the other, and back again" (p. 56). Kagle and Giebelhausen (1994) insist that any "dual relationships are potentially exploitive, crossing boundaries of ethical practice, satisfying practitioner needs and impairing his or her judgment" (p. 213). In his seminal treatise on boundaries, Epstein (1994) asserts that "monitoring boundaries is as essential to psychotherapy as maintaining aseptic technique in surgery" (p. 33).

Other writers suggest the dual relationships are inevitable especially in rural communities (Bader, 1994; Jennings, 1992; Stockman, 1990) and that absolutist positions are unrealistic and unnecessarily restrictive. Such authors state that the emphasis should be not on avoidance but on risk management (Gottlieb, 1993). Ginsberg (1998), for example, states that, "For rural workers, many relationships 
are multiple. One's friends, fellow church members, grocers, auto dealers and organizational colleagues may also be clients or may be related to clients" (p. 13). Simon and Williams (1999) write of the necessity to treat friends or relatives in certain situations and conclude, "The treatment of acquaintances that would be a boundary violation in larger cities may only require boundary adjustment in small or rural communities" (p. 1443). However, as Jerrell and Knight (1985) note:

Many commonly held beliefs about rural practice have been derived from the anecdotal reports of practitioners, but little systematic information exists by which to compare these findings on a larger scale. Nor is it possible to make generalizations about rural mental health practitioners from the literature available. (p. 331)

\section{SOCIAL RELATIONSWTH CLIENTS}

Intuitively, there would seem to be little doubt that professional boundary issues arise more frequently in the rural context. As Sterling (1992) notes, "Small community therapists sometimes accept referrals to treat people with whom they have had a social relationship and treat people who have close relations with each other" (p.116). Fenby (1978) writes of catching a ride to work with a neighbor who happens to be a client. Brownlee (1996) relates the experience of treating a client who happens to be the teacher of the therapist's daughter. Backlar (1996) writes of befriending a client and suggests that the therapist must sometimes exercise judgment and not al ways follow rules. Gates and Speare (1990) assert and Mazer (1976) agrees that overlapping relationships are built into the fabric of rural communities and see the positive aspects of observing clients in other contexts. As Catalano (1997) states, "In small communities, the therapist may have common social and professional contacts with and may know significant people in the other's life" ( $p$. 25). Despite such conclusions, we know little of the extent to which rural social workers maintain such relationships nor what they believe about the ethics of these behaviors.

\section{METHODOLOGY}

The study population consists of members of the National Association of Social Workers (NASW) who possess an M.S.W. and have identified themselves as being in "direct practice." This resulted in a sampling frame of 58,056 NASW members. A simple random sample of 1,200 was drawn from this population. After various exclusions (e.g., retirees, undeliverable addresses, etc.), the sample size was reduced to 1,143. Excluding those drawn in this random sample, additional random samples of 478 each were drawn from the following groups: AfricanAmerican, Asian-American, and Hispanic/Latina. In addition, a discrete random sample of $\mathbf{4 8 5}$ social workers in private practice was also drawn. This resulted in a total sample of 3,062 social workers in direct practice.

Based on cases presented before the Michigan Committee on Inquiry, a pre-test with professional practitioners in the State of Michigan and an extensive review of the literature, a 10-page questionnaire was developed to study the previously mentioned practice domains. The questionnaire was sent to each respondent along 
with a cover letter, a commitment postcard, and return envelope. If we did not receive the commitment postcard within three weeks, a second questionnaire, cover letter, and return envelope were mailed to the non-respondent. This procedure resulted in a return of 1,684 useable questionnaires for an overall response rate of $55 \%$.

For the purpose of this exploratory paper, we identified practitioners in rural and urban settings by their responses to the following question: "Are the clients seen in your agency mostly (70\% or more) from...." Those respondents who indicated "rural or farm communities (25,000 or less)" were identified as rural practitioners, and those respondents who indicated "a large city (500,000 or more)" were identified as urban practitioners. This procedure resulted in 126 respondents in the rural category and 441 respondents in the urban category.

\section{RESULTSAND DISCUSSION}

Tables 1 and 2 present specific items used to measure the dimensions of bartering, competency, confidentiality, multiple and dual relationships, and social relationships. The data in Table 1 present the respondents' beliefs about the appropriateness of the given behaviors in the larger professional context. In contrast, Table 2 presents information on the reported behaviors in question by the respondents.

\section{BARTERING}

Despite the debate over the use of bartering or the exchange of goods and services as payment for professional services, our data indicate that bartering in practice is a rare event with no significant differences between rural and urban practitioners. In fact, the responses are surprisingly similar given assertions that bartering for professional services is commonplace in the rural community. With regard to professional beliefs about the appropriateness of bartering, rural social workers are significantly different from urban practitioners in that they are more likely to approve of such behavior. These findings are similar to those reported by Horst (1989), Percival and Striefel (1994), and Pope, Tabachnick and Keith-Spiegel (1987). However, the data clearly indicate that beliefs about the appropriateness of bartering do not result in actual practice behaviors (see Table 2).

As Sonne (1994) notes, an exchange of services for treatment puts the client in the role of employee, a relationship placing the social worker in a potentially conflictual situation that may have implications for both ethics and social work licensing grievances. A compromise solution, one adopted by the Clinical Social Work Federation (1997), permits the exchange of goods but not services as payment. Such a compromise is at least partially responsive to those who have raised questions regarding whether the ethics of bartering arrangements may be worth further discussion. However, given the rarity of bartering in practice, onecan only conclude that "necessity is not the mother of invention," and the advice of Gutheil and Gabbard (1993) is well taken: "The clinician should take a case at a reasonable fee or make a decision to see a patient for a low fee (e.g., one dollar) or none. Bartering is confusing and probably ill advised today" (p. 193). 


\begin{tabular}{|c|c|c|c|c|c|}
\hline & Appropriate & Uncertain & Inappropriate & $\begin{array}{l}\mathrm{t}- \\
\text { value }\end{array}$ & Sig \\
\hline \multicolumn{6}{|l|}{ Bartering } \\
\hline $\begin{array}{l}\text { Accept goods or services } \\
\text { from client instead of money }\end{array}$ & & & & -2.745 & .01 \\
\hline Urban & $45(10.3 \%)$ & $84(19.2 \%)$ & $309(70.5 \%)$ & & \\
\hline Rural & $22(17.1 \%)$ & $31(24.0 \%)$ & 76(58.9\%) & & \\
\hline Competency & & & & -1.044 & ns \\
\hline \multicolumn{6}{|l|}{$\begin{array}{l}\text { Use treatment techniques } \\
\text { for which you received no } \\
\text { formal training }\end{array}$} \\
\hline Urban & $26(5.9 \%)$ & $59(13.4 \%)$ & $356(80.7 \%)$ & & \\
\hline Rural & $12(9.3 \%)$ & 17(13.2\%) & $100(77.5 \%)$ & & \\
\hline $\begin{array}{l}\text { Maintain Confidentiality } \\
\text { and Privacy }(\alpha=60)\end{array}$ & & & & -1.065 & ns \\
\hline \multicolumn{6}{|l|}{$\begin{array}{l}\text { Share confidential } \\
\text { information about client } \\
\text { with relatives without } \\
\text { client's consent when you } \\
\text { thought it was in the client's } \\
\text { best interest? }\end{array}$} \\
\hline Urban & $47(10.6 \%)$ & $44(9.9 \%)$ & $353(79.5 \%)$ & & \\
\hline Rural & 17(13.7\%) & $15(12.1 \%)$ & $92(74.2 \%)$ & & \\
\hline \multicolumn{6}{|l|}{$\begin{array}{l}\text { Share confidential } \\
\text { information about dient with } \\
\text { others (not family relatives) } \\
\text { without dient's consent when } \\
\text { you thought it was in the } \\
\text { client's best interest? }\end{array}$} \\
\hline Urban & $54(12.2 \%)$ & $52(11.7 \%)$ & $338(76.1 \%)$ & & \\
\hline Rural & $24(18.9 \%)$ & $10(7.9 \%)$ & $93(73.2 \%)$ & & \\
\hline $\begin{array}{l}\text { Engage in Multiple or Dual } \\
\text { Relationships }(\alpha=75)\end{array}$ & & & & -4.593 & .0001 \\
\hline \multicolumn{6}{|l|}{$\begin{array}{l}\text { Accept business associates } \\
\text { or co-workers as clients }\end{array}$} \\
\hline Urban & $32(7.0 \%)$ & $52(11.4 \%)$ & $371(81.6 \%)$ & & \\
\hline Rural & $16(12.4 \%)$ & $27(20.9 \%)$ & $86(66.7 \%)$ & & \\
\hline \multicolumn{6}{|l|}{$\begin{array}{l}\text { Have clients with whom you } \\
\text { haveanother relationship }\end{array}$} \\
\hline Urban & $30(6.7 \%)$ & $81(18.1 \%)$ & $337(75.2 \%)$ & & \\
\hline Rural & $22(17.1 \%)$ & $38(29.5 \%)$ & $69(53.4 \%)$ & & \\
\hline \multicolumn{6}{|l|}{$\begin{array}{l}\text { Accept relatives or friends } \\
\text { as clients }\end{array}$} \\
\hline Urban & $21(4.7 \%)$ & $26(5.8 \%)$ & 400(89.5\%) & & \\
\hline Rural & $11(8.7 \%)$ & 14(11.0\%) & 102(80.3\%) & & \\
\hline
\end{tabular}




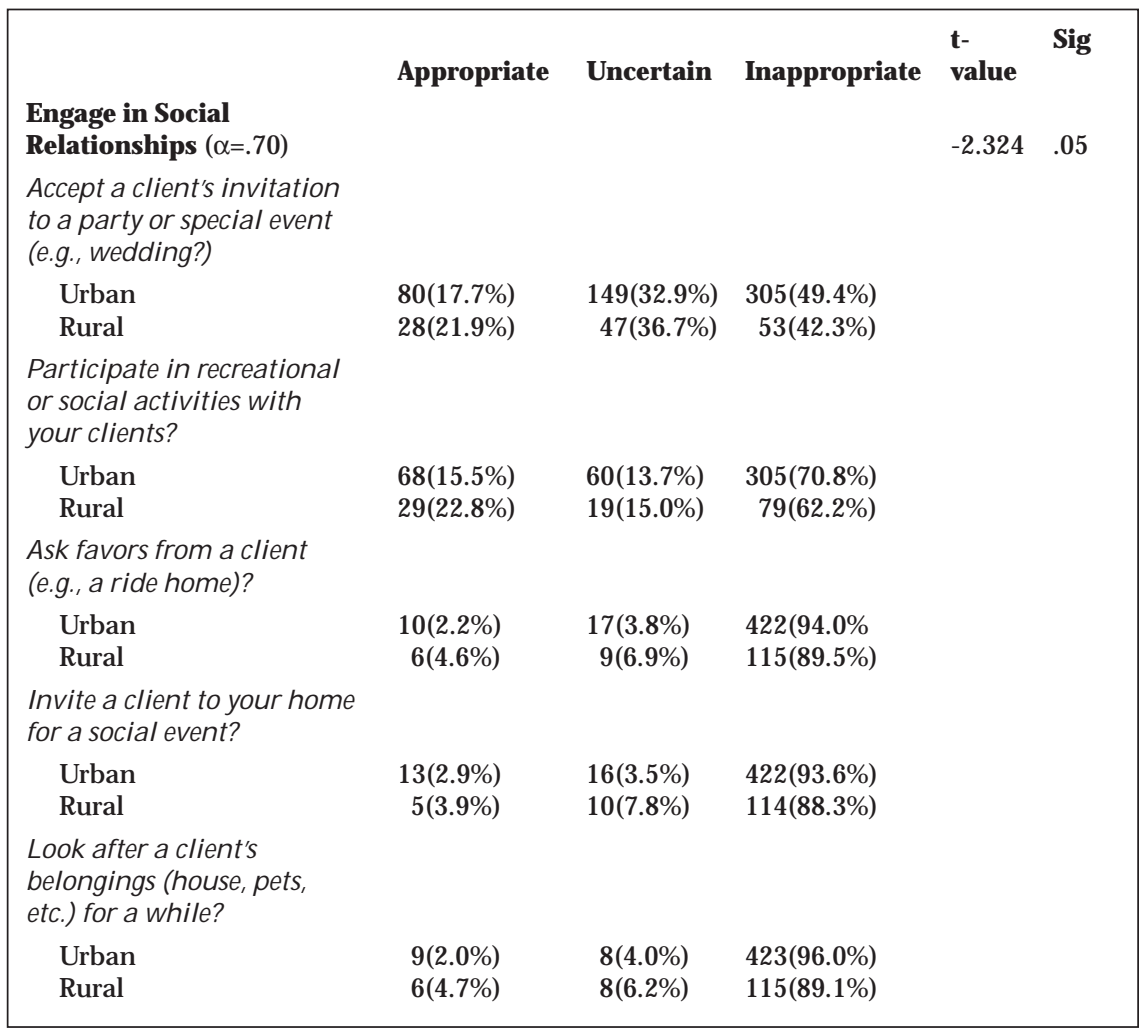

\section{COMPETENCY}

With regard to competency, we asked two simple questions. The first question inquired: How often haveyou used treatment techniques for which you havehad no formal training? There was no statistical difference in the responses of urban and rural social workers to this question; in fact, the responses from both sets of social workers were remarkably similar. This does not mean, however, that the data does not have significance in the larger context of social work practice. Across both groups, more than $20 \%$ of our respondents acknowledged that they had used treatment techniques without formal training at least once, with $8 \%$ acknowledging that they had done so three or more times. Such behavior is surprising on several levels and certainly has insurance and malpractice implications. Within the realm of ethics, these behaviors could put those social workers in apparent violation of the NASW Code of Ethics (1996), which states that:

Social workers should provide services in substantive areas or use intervention techniques or approaches that are new to them only after engaging in appropriate study training, consultation, and supervision from people who are competent in those interventions and techniques.(Sec. 1.04) 


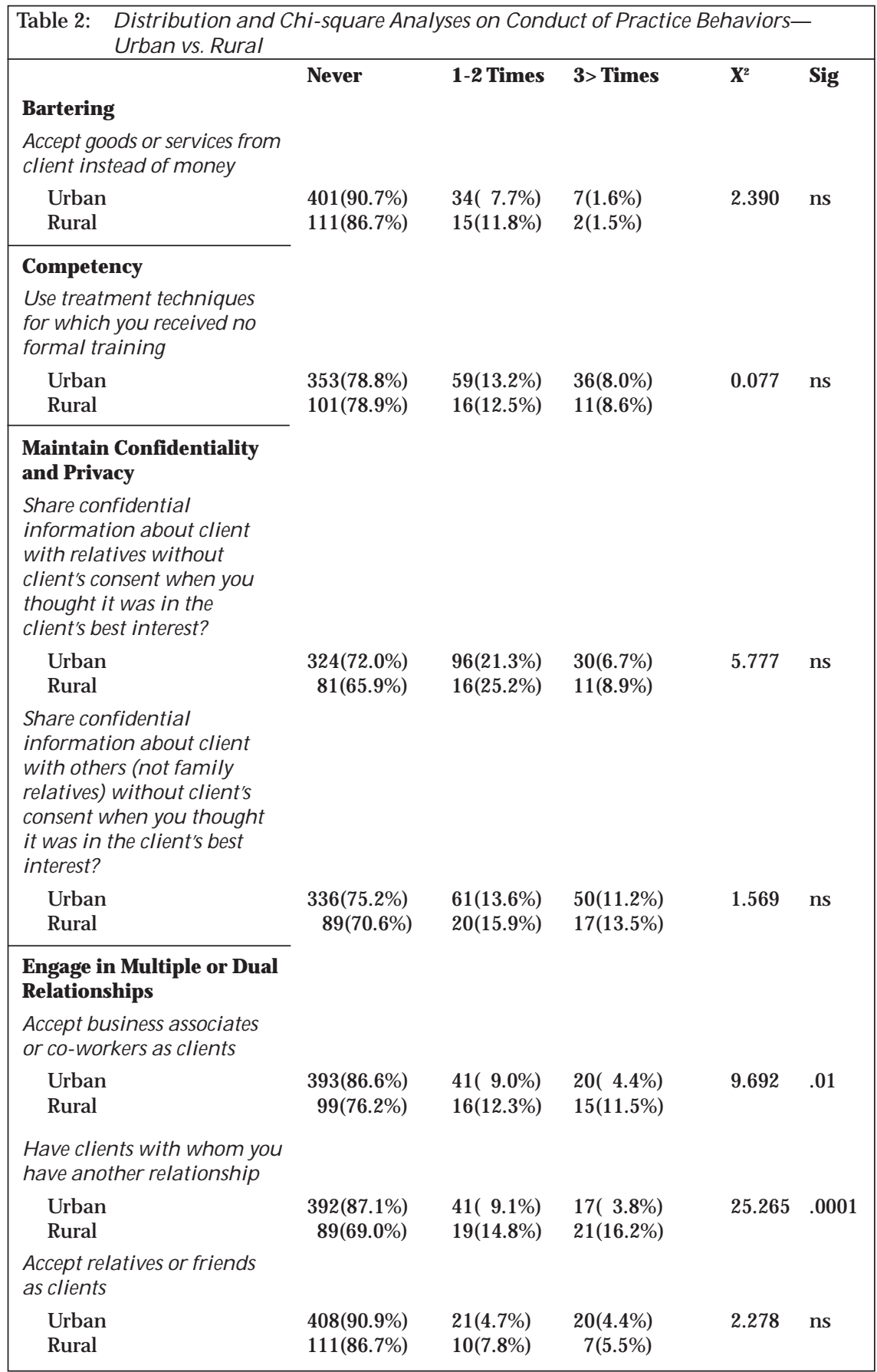




\begin{tabular}{|c|c|c|c|c|c|}
\hline & Never & 1-2Times & 3>Times & $X^{2}$ & Sig \\
\hline \multicolumn{6}{|c|}{ Engage in Social Relationships } \\
\hline \multicolumn{6}{|c|}{$\begin{array}{l}\text { Accept a client's invitation to } \\
\text { a party or special event (e.g., } \\
\text { wedding?) }\end{array}$} \\
\hline Urban & $261(57.6 \%)$ & $146(32.3 \%)$ & $46(10.1 \%)$ & 1.676 & ns \\
\hline Rural & $81(62.3 \%)$ & $40(30.7 \%)$ & $9(10.0 \%)$ & & \\
\hline \multicolumn{6}{|c|}{$\begin{array}{l}\text { Participate in recreational } \\
\text { or social activities with } \\
\text { your clients? }\end{array}$} \\
\hline Urban & $310(69.8 \%)$ & $86(19.4 \%)$ & $48(10.8 \%)$ & 3.193 & 3.193 \\
\hline Rural & $82(64.1 \%)$ & $23(18.0 \%)$ & $23(17.9 \%)$ & & \\
\hline \multicolumn{6}{|c|}{$\begin{array}{l}\text { Ask for favors from a dient } \\
\text { (e.g., a ridehome)? }\end{array}$} \\
\hline Urban & $417(92.5 \%)$ & $31(6.9 \%)$ & $3(0.6 \%)$ & 1.479 & ns \\
\hline Rural & 119(90.8\%) & $11(8.4 \%)$ & $1(0.8 \%)$ & & \\
\hline \multicolumn{6}{|c|}{$\begin{array}{l}\text { Invitea client to your home } \\
\text { for a social event? }\end{array}$} \\
\hline Urban & $431(94.9 \%)$ & $18(4.0 \%)$ & $3(1.1 \%)$ & 0.595 & ns \\
\hline Rural & $122(93.8 \%)$ & $7(5.4 \%)$ & $1(0.8 \%)$ & & \\
\hline \multicolumn{6}{|c|}{$\begin{array}{l}\text { Look after a client's belongings } \\
\text { (house, pets, etc.) for a while? }\end{array}$} \\
\hline Urban & $445(98.0 \%)$ & $8(1.7 \%)$ & $1(0.3 \%)$ & 3.418 & ns \\
\hline Rural & $126(96.2 \%)$ & $5(0.8 \%)$ & $0(0.0 \%)$ & & \\
\hline
\end{tabular}

The second question inquired: How succesful would you say you were with your most recently terminated client? Interestingly, $14.1 \%$ of the rural social workers compared to $5.0 \%$ of the urban social workers reported they were unsuccessful $\left(X^{2}=7.451, p<01\right)$. We can only speculate why nearly three times as many rural practitioners report lack of success compared to their urban counterparts. It is possible, for example, that the rural social workers have less collegial or supervisory support, fewer options available for clients, or are simply faced with more difficult problems.

\section{CONFIDENTIALITY}

To measure the importance of confidentiality, we asked two questions (see Tables 1 and 2). As these data indicate, there are no significant differences between the rural and urban social workers with respect to behaviors and beliefs surrounding confidentiality. Most respondents attended to the importance of confidentiality in the professional relationship with equal concern and rigor. This does not discount nor minimize the difficulty in preserving confidentiality in the rural community, where pressure to reveal or maintain confidences may, indeed, be greater. Nor do the responses attend to assertions regarding common community knowledge of professional relationships. Our data only indicate that professional beliefs about confidentiality and maintaining confidentiality are not dependent on community 
size. That is, regardless of practice location, social workers place high value on the principle of confidentiality.

\section{MULTIPLE OR DUAL RELATIONSHIPS}

Our data indicate that there are significant differences between urban and rural social workers in both practice behaviors and beliefs with regard to multiple or dual relationships. However, it should be noted that these differences may be partially explained by the responses to an ambiguous question, that is, Do you have clients with whom you have another relationship? What is clear, however, is that almost $70 \%$ of rural social workers, compared to $85 \%$ of rural social workers, report not having another relationship with clients, thus, contradicting those who maintain such contacts are inevitable. Yet, three times as many (17.1\%) rural social workers compared to urban social workers (6.7\%) consider such relationships appropriate. In addition, nearly a third (29.5\%) of rural social workers compared to urban practitioners (18.1\%) report uncertainty about the appropriateness of this behavior.

It is also noteworthy that accepting business associates and co-workers as clients is more common among rural practitioners, with $23.8 \%$ having done this at least once compared to $13.4 \%$ of urban practitioners. In addition, rural workers are also far more likely (33.3\%) compared to urban workers (18.4\%) to consider such behavior appropriate. In contrast, accepting relatives and friends as clients is a relatively rare occurrence, with little difference between rural and urban practitioners. Taken as a whole, these data indicate a substantial difference between rural and urban practitioners in both practice behaviors and beliefs. Without additional interpretation and guidance, code provisions related to dual and multiple relationships may pose significant dangers for rural practitioners.

\section{SOCIAL RELATIONSHIPS}

Despite what the literature suggests as the inevitability of engaging in social relations with clients in rural environments, we found no statistical difference between urban and rural social workers in the behaviors considered in this study. In fact, the responses are again remarkably similar. With regard to accepting a client's invitation to a special occasion or participating in recreational or social events with clients, nearly one-third of both urban and rural practitioners had done so once or twice. With regard to invitations for social contact initiated by the social worker, $90 \%$ of our respondents had never extended such invitations irrespective of community size. It is noteworthy, however, that with regard to clientinitiated requests, our respondents indicated a good deal of uncertainty about the appropriateness of the behaviors mentioned, especially what to do when a client invites the worker to a party or special event, for example, a wedding.

\section{IMPLICATIONSAND LIMITATIONS}

On one hand, the research presented here within the context of ethics suggests that the teaching of social work values and ethics at the graduate level is strong enough to withstand environmental pressures, and that despiteconcerns raised in the literature, there is a broad acceptance of the professional code of ethics across both urban and rural practitioners. On the other hand, the level of uncertainty 
about the appropriateness of specific behavioral responses, especially among those who practice in rural settings, suggests that schools of social work and the profession should give more attention to the ethical dilemmas faced by rural social workers.

It should be noted that the data presented here is confined to those in direct practice and excludes social workers who utilize other professional intervention methods such as community practice and administration. In addition, the data do not present a picture of any urban/rural differences as reflected in cases actually brought before the professional Committee on Inquiry. Neither do we know whether the same results would be obtained in a survey of social workers employed at the Bachelor of Social Work level. Indeed, whether the current NASW Code of Ethics is efficacious for those practicing other than clinical social work is a matter for continuing debate and research.

\section{CONCLUSIONS}

Based on the behaviors explored in this study, there appears to be a remarkable congruence between the practice behaviors and beliefs of rural and urban social workers. Except for differences in beliefs regarding the appropriateness of bartering and entering into multiple or dual relationships with clients, urban and rural social workers appear to have similar practice beliefs and professional behaviors. Given the rarity of bartering in practice in both urban and rural communities and in recognition of the potential conflicts of interest involved, perhaps the exchange of goods and services for social work intervention should be categorically prohibited. With regard to multiple or dual relationships with clients, differences between rural and urban practitioners, and the level of uncertainty about appropriateness among all respondents suggest that further clarification and more specific guidelines are needed. In the broadest sense, rural practitioners are more likely to consider all behaviors identified in this study as appropriate (albeit in small percentages). At the same time, rural social workers are also more likely to express greater uncertainty about the appropriateness of the behaviors in question. Thus, the rural practitioner appears to be enmeshed in a series of ethical dilemmas that demand additional attention within the curricula of professional education and resolution by social worker ethicists. More disturbing for the profession as a whole is the reported use by both urban and rural social workers of intervention techniques without the benefit of formal training.

\section{References}

American Psychological Association. (1992). Code of Ethics. Washington, DC: Author.

Austin, C., Mahoney, K., \& Seidl. F. (1978). Exploring the base for rural social work practice. Human Services in the Rural Environment, 3(6), 7-21.

Backlar, P. (1996). The three r's: Roles, relationships, and rules. Community Mental Health, 32(5), 505-509.

Bader, E. (1994). Dual relationships: Legal and ethical trends. Transactional AnalysisJournal, 24(1), 64-66.

Borys, D.S., \& Pope, K.S. (1989). Dual relationships between therapists and clients: A national study of psychologists, psychiatrists and social workers. Professional Psychology: Research and Practice, 25(5), 283-293. 
Brownlee, K. (1996). The ethics of non-sexual dual relationships: A dilemma for the rural practitioner. Community Mental Health Journal, 32(5) 497-503.

Carlton-LaNey, I.B., Edwards, R.L., \& Reid, P.N. (Eds.). (1999). Preserving and strengthening small towns and rural communities. Washington, DC: NASW Press.

Castle, E.N. (Ed.). (1995). The changing American countryside: Rural people and places. Lawrence, KS: University Press of Kansas.

Catalano, S. (1997). The challenge of clinical practice in small rural communities: Case studies in managing dual relationships in and outside of therapy. Journal of Contemporary Psychotherapy, 27(1), 23-35.

Clinical Social Work Federation (1997). Code of Ethics. Washington: DC: Author.

Cook, A.F., Hoas, H., \& Joyner, J.C. (2001). No secrets on main street: Challenges to ethically sound care in the rural setting. American Journal of Nursing, 101(8), 67-71

Davenport, J.A., \& Davenport, J. (1995). Rural social work overview. Encyclopedia of Social Work, (19 ed.), Vol. 3. Washington, DC: NASW Press.

Doelker, R.E., \& Bedics, B.C. (1983). An approach to curriculum design for rural practice. Journal of Social Work Education, 19(1), 39-46.

Erickson, S.H. (2001). Multiple relationships in rural counseling. FamilyJournal-Counseling \& Therapy for Couples and Families, 9(3), 302-304.

Epstein, R. (1994). Keeping boundaries. Washington, DC: American Psychiatric Press.

Farley, O.W., Griffiths, K.A., Skidmore, R.A., \&Thackeray, M.G. (1982). Rural social work practice New York: The Free Press.

Fenby, B.L. (1978). Social work in rural setting. Social Work, 23(2), 162-163.

Gates, K.P., \& Speare, K.H. (1990). Overlapping relationships in rural communities. In H. Lerman \& N. Porter (Eds.), Feminist ethics in psychotherapy (pp. 97-101). New York: Springer.

Ginsberg, L.H. (Ed.). (1998a). Social work in rural communities, (3 $3^{\text {rd }}$ ed.). Alexandria, VA: Council on Social Work Education.

Ginsberg, L.H. (1998b). Introduction: An overview of rural social work. In Social Work in Rural Communities ( $3^{\text {rd }}$ ed.). Alexandria, VA: Council on Social Work Education, pp. 3-22.

Gottlieb, M.C. (1993). Avoiding exploitative relationships: A decision-making model. Psychotherapy, 30, 41-48.

Green, R.K., \& Webster, S.A. (Eds.). (1976). Social work in rural areas: Preparation and practice. Knoxville, TN: The University of Tennessee.

Gumpert, J., and Saltman, J.E. (1998). Social group work practice in rural areas. Social Work with Groups, 21(3), 19-34.

Gutheil, T.G., \& Gabbard, G.O. (1993). The concept of boundaries in clinical practice: Theoretical and riskmanagement dimensions. American Journal of Psychiatry, 150(2), 188-196.

Hargrove, D.S. (1986). Ethical issues in rural mental health practice. Professional Psychology: Research and Practice, 17, 20-23.

Hartlaub, G.H., Martin, G.C., \& Rhine, M.W. (1986). Recontact with the analyst following termination: A survey of seventy-one cases. Journal of theAmerican Psychoanalytic Association, 34(4), 885-910.

Horst, E.A. (1989). Dual relationships between psychologists and clients in rural and urban areas. Journal of Rural Community Psychology, 10(2), 15-24.

Jaffee v. Redmond, 518 U.S. 1 (1996).

Jennings, F.L. (1992). Ethics in rural practice. Psychotherapy in PrivatePractice, 10(3), 85-104.

Jerrell, J.M., \& Knight, M.S. (1985). Social work practice in community mental health systems. Social Work, 30(4), 331-337.

Johnson, N.E., \& Wang, C. (Eds.) (1997). Changing rural social systems: Adaptation and survival. East Lansing, MI: Michigan State University Press.

Johnson, W.H. (Ed.). (1980), Rural human services. Itasca, IL: F.E. Peacock Publishers. 
Jones, S. (Ed.). (1993). Sociocultural and serviceissues in working with rural dients. Albany, NY: University of Albany.

Jones, S.J., \& Zlotnick, J.L. (1998). Preparing helping professionals to meet community needs: Generalizing from therural experience. Alexandria, VA: Council on Social Work Education.

Kagle, J.D., \& Giebelhausen, P.N. (1994). Dual relationships and professional boundaries. Social Work, 39, 213-220.

Lyckholm, L., Hackney, M.H., \& Smith, T.J. (2001). Ethics in rural health care. Critical Reviews in Oncology/Hematology, 40(2), 131-138.

Martinez-Brawley, E. (1993). Preparing rural human service workers: What should they learn?What can we teach. In S. Jones (Ed.). Sociocultural and service issues in working with rural clients (224-238). Albany, NY: University of Albany.

Martinez-Brawley, E. (1999). Close to home: Human services and the small community. Washington, DC: NASW Press.

Mattison, D., Jayaratne, S., \& Croxton, T. (2002). Client or former client: Implications of ex-client definition on social work practice. Social Work, 47(1), 55-64.

Mazer, M. (1976). People and predicaments (of life and distress in Martha's Vineyard). Cambridge, MA: Harvard University Press.

Mermelstein, J., \& Sundet, P.A. (1995). Rural social work in an anachronism: The perspective of thirty years of experience and debate. Human Services in the Rural Environment, 18(4), 5-12.

Miller, P.J. (1994). Dual relationships in rural practice. Human Services in the Rural Environment, 19(1), 5-12.

National Association of Social Workers (1996). Code of Ethics. Washington, DC: Author.

Nelson, M.K., \& Smith, J. (1999). Working hard and making do: Surviving in small town America. Berkeley, CA: University of California Press.

Percival, G., \& Striefel, S. (1994). Ethical beliefs and practices of AAPB members. Biofeedback and SelfRegulation, 19(1), 67-93.

Pope, K. (1991). Dual relationships in psychotherapy. Ethics and Behavior, 1(1), 21-34.

Pope, K., Tabachnick,B., \& Keith-Spiegel, P. (1987). Ethics of practice: The beliefs and behaviors of psychologists as therapists. American Psychologist, 42(11), 993-1006.

Ramsdell, P.S., \& Ramsdell, E.R. (1993). Dual relationships: Client perceptions of the effect on client-counselor relationship on the therapeutic process. Clinical Social Work Journal, 21(2), 195-212

Reamer, F.G. (1994). Social work mal practice and liability. New York: Columbia University Press.

Reamer, F.G. (1998). Ethical standards in social work. Washington, DC: NASW Press.

Reamer, F.G. (1999). Social work values and ethics, (2 ed.). New York: Columbia University Press.

Reamer, F.G. (2001). The Social Work ethics audit. Washington, DC: NASW Press.

Rinella, V., \& Gerstein, A. (1994). The development of dual relationships: Power and professional responsibility. International Journal of Law and Psychiatry, 17(3), 225-237.

Roberts, L.W., Battaglia, J., \& Epstein, R.S. (1999). Frontier ethics: Mental health care needs and ethical dilemmas in rural communities. Psychiatric Services, 50(4), 497-503.

Roberts, L.W., Battaglia, J., Smithpeter, M., \& Epstein, R.S. (1999). An office on main street: Health dilemmas in small communities. The Hastings Center Report, 29(4), 28-37.

Robison. W., \& Reeser, L.C. (2000). Ethical decision-making in social work. Boston: Allyn and Bacon.

Schank, J.A. (1998). Ethical issues in rural counselling practice. Canadian Journal of Counselling, 32(4), 270-283.

Schank, J.A., \& Skovholt, T.M. (1997). Dual relationship dilemmas of rural and small-town community psychologists. Professional Psychology: Research and Practice, 28(1), 44-49.

Silbertrust, D.C. (1993). Post-termination dual relationships: What our former clients tell us. Dissertation Abstracts International, 53, 3793-B. 
Simon, R.I., \& Williams, I.C. (1999). Maintaining treatment boundaries in small communities and rural areas. Psychiatric Services, 50(11), 1441-1446.

Sobel, S.B. (1992). Small town practice of psychotherapy: Ethical and personal dilemmas. In R.D. Weitz (Ed.), Psychotherapy in private practice: Psychological practice in small towns and rural areas, (pp. 6169). New York: Haworth Press.

Sonne, J.L. (1994). Multiple relationships: Does the new code answer the right questions. Professional Psychology: Research and Practice, 25(4), 336-343.

Spiegel, P.B. (1990). Confidentiality endangered under some circumstances without special management. Psychotherapy, 27(4), 636-643.

Sterling, D.L. (1992). Practicing rural psychotherapy: Complexity of role and boundary. Psychotherapy in PrivatePractice, 10(3), 105-127.

Stockman, A.M. (1990). Dual relationships in rural mental health practice: An ethical dilemma. Journal of Rural Community Psychology, 11(2), 31-45.

Thompson, A. (1990). Guideto ethical practice in psychotherapy. New York: John Wiley \& Sons.

Tolson, E., Reid, W.J., \& Garvin, C.D. (1994). Generalist practice: A task-centered approach. New York: Columbia University Press.

Waltman, G.H. (1986). Main street revisited: Social work practice in rural areas. Social Casework: The Journal of Contemporary Social Work, 67(8), 466-474.

Weitz, R.D. (Ed.) (1992). Psychological practicein small townsand rural America. New York: Haworth Press. Welfel, E.R. (1998). Ethics in counseling and psychotherapy. Pacific Grove, CA: Brooks/ Cole Publishing.

Whitaker, W. (1986). A survey of perceptions of social work practice in rural and urban areas. Human Services in the Rural Environment, 9(3), 12-19.

York, R., Denton R., \& Mogan, J. (1989). Rural and urban social work practice: Is there a difference? Casework: The Journal of Contemporary Social Work, 70(4), 201-209.

Young, C.L., \& Martin, D.M. (1989). Social services in rural and urban primary care projects. Human Services in the Rural Environment, 13(2), 30-41.

Younggren, J., \& Skorka, D. (1992). The non-therapeutic psychotherapy relationship. Law and Psychology Review, 16, 13-28.

\section{Author's Note:}

This study was partially funded by the NASW Michigan Chapter, and the authors are indebted to the Chapter's Executive Director and the Executive Board.

Address correspondence to: Srinika Jayaratne, Ph.D., Professor, School of Social Work, The University of Michigan, 1080 South University, Ann Arbor, MI 48109-1106, USA. E-mail: sirijay@umich.edu. 